\title{
The Processes of Teaching Languages to Sixth Grade Students in an International Immersion School in a Midwestern City, U.S.A
}

\author{
Faisal S. Alzahrani: Ministry of Education, Riyadh, Saudi Arabia.
}

\begin{abstract}
This paper examines the teaching strategies used in an international immersion school in a Midwestern city in the U.S.A. A good number of teaching strategies are highlighted in literature review to provide context for this particular study. The immersion program is considered a teaching strategy and an additional name for bilingual schools in which students learn through a second language's environment with the purpose of developing proficiency in two languages. The significance of this study is that students in immersion schools should have the same quality of education as their peers have in public schools. The participants in this study used the cognate, cooperative, structural strategies and other strategies in teaching the second language itself or when teaching subjects in the students' second language. This study is a basic qualitative research and the data was collected though observations and interviews. The data was analyzed by using the ground theory approach. This study shows that immersion schools help students to achieve their second language acquisition and help them in the future to have the ability to access different languages of curriculum. Because the school is under development, this is one limitation that is presented in this study.
\end{abstract}

Key words: Teaching Strategies, Motivations, Immersion schools, Language acquisitions.

\section{Introduction and Rationale}

Bilingualism is an important topic globally. Almost half of the world's population speaks more than one language (Al-Mansour, 2009). Bilingualism exists in every country around the world, regardless of social class or age. A great many young children live in bilingual or multilingual environments (Grosjean, 1982). Establishing a solid bilingual program in these sorts of environments is crucial. Research confirms that students benefit from bilingual education or immersion programs (Cummins, 2009; Cummins, 2007). There are approximately 5000 languages spoken in the world and two thirds of all children in the world grow up in a bilingual or multilingual environment (Cummins, 2009). Bilingualism is defined and applied in different ways in school settings; therefore, researchers agree that there is more than one type of bilingualism, and bilingual education has a number of categories. Increasing bilingualism in a society, region or country can have numerous benefits educationally, economically, and socially. Also, Cummins (2009) describes bilingual education by saying that a bilingual program is a program that uses two or more languages in instruction, and is used to teach subject matter or materials rather than merely teaching the languages themselves.

Cummins (2009) adds that the term "immersion" program is considered an additional name for bilingual programs in which students learn through a second language's environment with the purpose of developing proficiency in two languages. In other words, at least half of the school's academic instruction is given in the second language; examples of this include the French immersion program in Canada and the dual lingual program in the U.S, which is similar to programs in Europe. The term "immersion" could be used also in the bilingual program in a different way, which is learning through a second language with the aim of developing proficiency only in the language of instruction. "Submersion" is an appropriate term for this kind of 
education, and it focuses on the use of the minority students' first language to integrate them into their second language society and school system. This is typical of, for example, Spanish- speakers in the U.S, Turkishspeakers in Germany, and I would add, Arabic speakers in Windsor, Ontario.

Indeed, a bilingual program can be established at any level of education starting from pre-school through the university or college level. The purposes of bilingual education and immersion schools are to prepare students for the future and for academic achievement. Some educators are opposed to bilingual programs and some hold erroneous beliefs about immersion programs; however, many published studies suggest that bilingual education is the best method to educate children. These programs have already been established in many countries, and these countries have seen the advantages of bilingual education or immersion programs for their children. Many researchers have discussed how to move these programs into the $21^{\text {st }}$ century. For example, Garica, Flores, and Chu (2011) point out that throughout the 20th century Canadian and U.S. experts have claimed that bilingualism can be established through either an additive or subtractive program. In a subtractive program, students' first language is subtracted, as the second language is learned. On the other hand, students in an additive program add the language of the school together with their home language.

Consequently, there is no disagreement about the importance of bilingual education or immersion school for students. In pervious courses, I studied the importance of enrolling children in immersion schools or any bilingual programs because of the advantages that those kinds of programs have for students. I also highly recommended establishing immersion schools or any bilingual education program in my home country's educational systems. These programs should be available and free of charge in all Saudi Arabian cities. After studying the advantages of immersion schools for the students, I became more interested in studying how students learn languages. Merriam (2009) outlined that, "A topic might come from the literature, especially previous research or theory in an area. Something you read in your association newsletters, a paper you write for a course assignment, or even leisure reading may be the source of a question that can evolve into a research study" (p. 57).

As a result, this paper examined how a first language and second language are learned in a middle immersion school. I tried to deeply look at the teaching strategies and students' linguistic achievement. Merriam (2009) stated that, "a focus means deciding what you want to tell your reader. You should be able to state it in a sentence or two" (p. 241). The purpose of this study was to examine the teaching strategies used by the international immersion school's teachers in Mid-West City Language Immersion School in the immersion classroom. Teachers use multiple of teaching strategies and I focused on the most useful strategies that can help students achieve their goals. Plus, a teaching strategy does not work by itself; learners' behaviors must also be changed so that learners can be pushed to learn more positively. In order to discuses the teaching strategies, there are some factors that must be addressed, such as challenges faced by immersion schools that are not faced in regular schools. Therefore, the importance of this study is that students in immersion schools should have the same quality of education as their peers have in public schools.

Creswell (2007) stated that, "The process of designing a qualitative study begins not with the methods... To study [the] topic, we ask open-ended research question, wanting to listen to the participants we are studying and shaping the questions after we 'explore,' and we refrain from assuming the role of the expert researcher with the 'best' questions" (p. 42, 43). When I planned to study the sixth grade students in the international immersion school, I had three research questions. After collecting the data and analyzing it, I came up with different questions and I narrowed them down to be more concise than before the study processes. According to Creswell (2007) "Our questions change during the process of research to reflect an increased understanding of the problem" (p. 43).

This study answered the research questions and sub-questions, which were:

Q 1. What teaching strategies do the international school's teachers in the International school use in the sixth grade immersion classroom?

Q.1.1 What teaching strategies work best for immersion classroom?

Q.1.2 How can these strategies be more effective for sixth grade students?

Q.1.3 What are the biggest challenges for teaching in immersion schools?

Q 2. How do sixth grade students acquire their second language in the immersion program?

This paper introduced briefly some previous studies about the differences between students in immersion schools and regular schools, second language teaching methodologies, and motivation. Then, it 
explained the study method with descriptions of the participants and the study's site. The paper also addressed methods of collecting data and the way of analyzing the collecting data. It finally outlined the findings of this study including the study's discussions and the limitations of the current study.

\section{Literature Review}

Even though students in the immersion program need extra support in both first language and second language, they greatly acquired the languages and different materials of subjects in both languages. Studies usually show that bilingual programs are a plus for children. Slavin and Cheung (2005) examined 17 studies on the effects of bilingual education. Twelve of these studies found evidence that favored bilingual education; the other 5 studies showed that the bilingual approach has no effect on student achievement. None of the studies' results favored a monolinguist approach. They also noted that most of these studies were conducted in the 1970's, and during this time, the topic of bilingual models was popular. Nevertheless, they emphasized that: "Research on language of instruction, reviewed most recently by and Slavin and Cheung (2005) (in press), has generally found that bilingual programs are more effective than (the first language) only programs" Slavin and Cheung (2005). When students are taught to read and write in their first language and in English, especially at the early levels of education, there is evidence of higher rates of success. Bialystok (2001) found that it is possible, if not advantageous, for students to reach high levels of proficiency in more than one language. In fact, students can perform at similar levels as native speakers, even if they do not use the language of instruction at home. Portes and Hao (1998) also examined the relationship between communicating in two languages and academic performance. They found that bilingualism is associated with both higher achievement and more ambitious future aspirations.

Cummins (2007) who has studied bilingualism in immigrant children for many years, states that these children using the first language to learn a second language may not achieve a high level in that learned language. But, when students learn through bilingual programs, this can function as a stepping-stone for greater accomplished performance as a cognitive and linguistic resource in the second language. For example, the students in French immersion schools in Canada are not only developing French language skills, but are also "developing a deeper conceptual and linguistic proficiency that is strongly related to the development of literacy in the majority language (English)" (Cummins, 2007). In other words, bilinguals have the ability to transform/ translate cognitive, academic, or literacy related proficiency from one language to another.

Therefore, research confirms that students in a bilingual program perform better than others in a regular education program. Sampath (2005) studied the differences between bilinguals and monolinguals among tenyear-old children in India. The bilingual children spoke Telugu at home and Tamil in the school. Tamil is the language of instruction in the school. Some of the bilingual children in this study spoke below average Tamil (their second language), some performed with average competency, and the remaining performed with above average competency. The monolingual children spoke Tamil at home and in school. Sampath (2005) tested thirty bilingual students and 30 monolingual students. The results show that "In a monolingual environment, learning through second language has beneficial effect on certain dimensions of nonverbal intelligence and on verbal intelligence" Sampath (2005). When bilingual children have a higher level of second language proficiency, they perform better on verbal intelligence and non-verbal intelligence tests. But, the level of proficiency in a second language does not affect logical reasoning and perceptual analyzing or organizing. Nevertheless, all bilingual children, regardless of their level, have the ability to solve mathematical problems, understand social judgments and social conventions, and develop concepts verbally.

In the same fashion, 162 children were divided into three groups, which included an English monolingual group, a French monolingual group, and an English-French bilingual group. All of these children were tested individually. The test contained five tasks in order to assess language proficiency, word mapping, and executive control. Bialystok, Barac, Blaye, and Poulin-Dubois (2011) found that these tests showed clear advantages for bilingual children. The bilingual students scored higher in the language proficiency and word mapping tasks; they were able to shift between the two languages, named items appropriately, and had fewer errors in the opposite word task. The opposite word task requires children to assign incongruent labels to a sequence of animal pictures. Bilinguals had higher scores than monolinguals in these tests. This study also found that bilingual children develop control over executive processes, such as control of attention, working memory (planning and maintaining set), and shifting between two languages, earlier than monolingual 
children. As well, bilingual children performed better than monolingual children on the task that required them to resolve conflict between competing responses.

Carlson and Meltzoff (2008) examined 50 kindergarten children. As in the previous study, these children were also divided into three groups. The first group contained 12 bilingual children. This group had been bilingual since birth. They were considered bilingual because either both parents spoke English and Spanish at home or in the community, or one of their parents spoke an additional language. For example, both parents may speak English, but the mother may speak Spanish too. The second group consisted of 21 children who enrolled in a program that offered half of the day in English instruction and the other half in either Spanish or Japanese instruction. This group was called the immersion group, and these children spoke only English prior to starting this program. The third group is known as the control group, and included 17 English monolingual children who attended a preschool without receiving exposure to a second language. The results show that "there was a significant relative advantage of native bilingualism on a composite of all tasks, and in particular, the subset of tasks involving conflicting attention" (Carlson \& Meltzoff, 2008). The immersion group performed better than the control group in executive functioning with verbal ability and socioeconomic status (SES). Finally, the control group performed similar to the immersion group on the individual and combined measures.

Likewise, Cummins (2009) outlined the positive outcomes of French immersion programs in Canada. Students who enrolled in this program early "gain[ed] fluency and literacy in French at no apparent cost their English academic skills" (p. N/A). Moreover, there are no differences in English test performance between immersion students and students who are in regular English schools. Additionally, immersion students have no problem in developing writing in English. Teaching through a second language has not affected first language literacy development, and immersion students are able to develop decoding skills in French even if their French proficiency is limited in the early stages of learning the language. Most immersion students develop English decoding skills in grade 1 and 2, without being given formal instruction in English.

Regarding teaching strategies, there are many studies that have been done on this issue but my focus was on teaching strategies for second language teaching. A good number of studies have been done on this issue as well. Cummins (1998) listed some significant teaching strategies that will help students to achieve their goals in the languages as well as in the subjects taught in students' second language. These strategies are: the structural approach, where the learners use their knowledge to learn or to build new knowledge above their previous knowledge. The old knowledge can be in students' first language and it does not affect the learning process. The second strategy is "Modifying instruction to build sufficient redundancy into the instruction (e.g. through paraphrase, repetition, demonstration, gestures etc.)" (Cummins, 1998). Thirdly, he recommended teachers to use graphics, charts, tables, and so on to explain the conceptual contexts. Next, teachers should use much more of practical activities in content areas such as Science, Mathematics, and Social Studies. Then, the author highly suggested the use of multiple technologies in the immersion classrooms. Cooperative learning is a good strategy as well with more focus on the team project and exchange experiences than on collecting information. Finally, the author suggested improving the reading and writing skills using a variety of the earlier strategies.

Abbasi (2011) examined the teaching strategies that English teachers used in English as second language (ESL) classrooms in India. Also, he suggested some successful teaching strategies that should be used in ESL classrooms. The data from his study was collected through interviews and survey questionnaires. The participants of this study were 20 private school and 20 public school teachers. The sample of participants was randomly selected from each school. Those teachers taught English to ESL learners at an intermediate level in a school in the city Jacobabad Sindh. Both interviews and questionnaires investigated all the widely used teaching strategies and how they were applied in their ESL classrooms. The data was analyzed using a computer program. The findings of this study were that there were a good number of strategies that help students in both private and public schools to acquire their second language and make their learning more enjoyable. The examples for the most useful second language teaching strategies are: translation, memorization, grammar and word activities, as well as cognate activities, and problem solving that could be inclusive (team problem solving).

Motivation is a very important matter that makes the teaching strategies more useful and the learning easier. In order to show the importance of motivation in learning, there should be a brief explanation about

\author{
Studies \\ Vol. 3, No.2, pp. 53-65 \\ 2020 \\ DOI: 10.53935/2641-533x.v3i2.141 \\ Funding: This study \\ Article History: \\ Received: 8 May 2020 \\ Revised: 10 June 2020 \\ Published: 12 August 2020 \\ (C) 2020 by the authors; licensee Academic \\ Publishing Group
}


what motivation is. While there are some debates about how to define motivation, Dornyei, a leading researcher in the motivation of second language learners, stated (1998) that the term motivation is commonly used in educational and research contexts. He defined motivation generally as "responsible for determining human behavior by energizing it and giving direction" (p.117). Also, he added, "Motivation is the process whereby goal directed activity is instigated and sustained" (p.118). In fact, there are numerous descriptions of motivation mentioned in his article. Practically speaking, motivation is an active process that includes active learning. It is a teaching and learning strategy that influences learners behaviorally and mentally, and leads to goal achievement. Dornyei (2008) believed that motivation in learning a second language is complex. Basically, motivation in second language learning is the extent "to which an individual works or strives to learn the language because of desire to do so and the satisfaction experienced in this activity" (p. 122). This definition shows that in order to stimulate motivation in second language learners, teachers should employ active learning, recognize that learners have the desire to learn a second language, and provide opportunities to perform and practice the second language.

Rahman, Jumani, and Basit (2010) investigated how motivation and demotivation affect ESL learners both positively and negatively. The participants in this study were 100 students in a higher secondary school in Pakistan. These participants were both male and female and all them were studying English as a compulsory subject at their higher secondary level. The data was collected through a questionnaire and the random sampling was used to select participants for this study. The data was computer-analyzed using Microsoft Excel XP and SPSS and the most important data was summarized in this paper.

Rahman et al. (2010) contend that, "Everybody needs to have motivation and a reason for action. Second and foreign language learners should be offered the opportunity to be motivated and fulfill their learning orientations" (p. 206). Both children and adults need to be motivated in acquiring English as a second language. When they had motivation, students were more interested in learning English and their learning was more enjoyable. Therefore, "Motivation is positively related to academic achievement of students" (p. 211). Additionally, Rahman et al. (2010) stressed that learners with high motivation learn and use the language much better than others who are less motivated. On the other hand, lack of motivation impedes language acquisition skills such as reading, writing, and speaking. The recommendations of this study were that teachers should focus on practical skills in teaching English, teachers need to focus on gender differences, and students should be educated on how to tackle social and peer pressure.

The relationship between these mentioned studies and this current study is that study continues to confirm that the immersion school is a good method for students to acquire their second language while simultaneously developing students' first language. Also, immersion schools have many features that will help students to easily learn languages, many more than can be found in other regular schools or language programs. In this research project, I have examined the important features that immersion schools have and how these features help students to learn. For example, on the first day of observation at the study site, I entered the international school, and noted that the school's signs are written in three languages. There were other features, too, which make the immersion school environment is very conducive to learning.

Immersion classroom strategies were mentioned in the literature. For example, classroom instruction is usually divided into two languages, $50 \%$ for the first language and the other $50 \%$ for the second language, or sometimes the language for class instruction depend on the level of students' language proficiency. There are still questions about how languages are taught for immersion students and which teaching strategies work very well for them. Next, I aimed in this study to go deeper to find which teaching strategies can be more effective for immersion students and make the learning of language easier. Although there was provided in the literature some educators who disagree regarding bilingual education, this was a challenge outside of the school environment, in this study; I further investigated what other challenges can happen inside the immersion classroom. In summary, I agreed with the literature about the importance of enrolling children in immersion programs, but liked to investigate to help those students to have the same quality of education. Also, I will provide some areas in this field that need further research.

\section{Research Method}

This is a basic qualitative research study. Merriam (2009) reasoned for using basic qualitative research by saying that "Qualitative researchers conducting a basic qualitative study would be interested in (1) how people interpret their experiences, (2) how they construct their world, and (3) what meaning they attribute to their

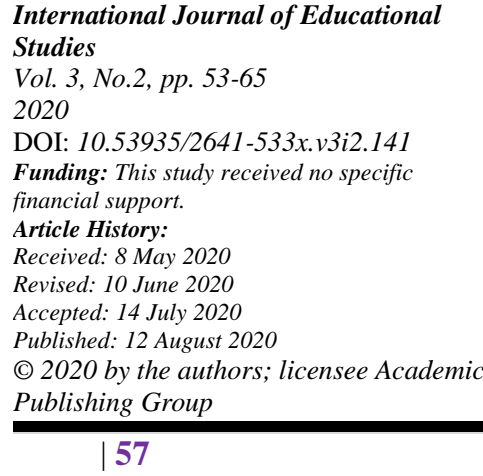


experiences. The overall goal is to understand how people make sense of their lives and their experiences." (p. 23). Therefore, I aimed in this study to understand how immersion classroom teachers teach a new language to non-native speakers, their experiences in teaching, their learning for more than one language, and how their teaching makes sense of their students' lives. I need to understand how immersion students acquire their second language without enrolling in language classes.

\subsection{Research Context}

This research study took place at an International Immersion School located in the downtown of a Midwestern city. This school is a part of the Midwest city's language immersion schools. Additionally they have Spanish, French and Chinese immersion schools. The school building is quite old, and it is divided into two programs. The first program is the Chinese immersion school, and it has a separate principal, teachers and staff for this program. Students are in this program from kindergarten until third grade. The second component is an international school, a new school in its first year. It has only one grade, which is sixth grade. In this school, there are a principal, three full-time teachers, one native French speaker and two native Spanish speakers, plus four part-time teachers. There are only thirty-five students. These students are native English speakers excluding two who have a Spanish background. Twelve of them are in a French- English program and twenty-three are in a Spanish-English program. The students in the program mostly divide into two groups, but sometimes into three to four groups. There are subjects taught only in French for students who are in a French classroom such as Design, Social Studies or French while other subjects are taught in Spanish such as Science and Spanish language for students who are in the Spanish classroom. All students in the school are taking courses in Science, Design, Music, and Mathematics in English only.

One day, I had a meeting with the school principal. I introduced myself to the principal, who wondered if I had a letter of approval from the school. I showed him my student ID and he again asked for the letter or an email from my advisor. I told him, "All the data will be completely confidential." One day later, he received an email from my class instructor that confirmed I would make observations in the school. The principal asked me, "What is your first language? Do you speak Arabic?" and I said yes. I thought he asked to know my nationality and I was surprised when he switched to speaking in Arabic. He speaks four languages: English, Spanish, French, and Arabic. Later, he took me for a short tour; we saw first the Chinese school and the students and their teachers in the classrooms. We moved to the international school but he did not show me the students or the classrooms. The principal introduced me to the native French speaking teacher and they had a short conversation; most of it was in French and little of it was in English.

\subsection{Participant Sampling}

Merriam (2009) and Creswell (2007) listed the popular strategies used in sampling participants, which are: typical, unique, maximum variation, convenience, and snowballing. In this study, the purposeful sampling was used; as my few participants are the ones who can answer my research question. I only observed two immersion classes and interviewed three teachers. Creswell (2007) stated, "The inquirer selects individuals and sites for study because they can purposefully inform an understanding of the research problem and central phenomenon in the study"(p. 125). Thus, those teachers were chosen because they were the only full-time teachers. They were also the ones who were teaching in the immersion classrooms. Mrs. Nancy was the French immersion teacher. She taught French language, social science, and design immersions. Mrs. Julia was the Spanish immersion teacher and she taught Spanish Science immersion. Mrs. Maria is also a science teacher, teaching Spanish Math immersion at the advanced level and Spanish Science for intermediate level students. I observed Mrs. Nancy's French immersion class and Mrs. Julia's Spanish Science immersion class.

In fact, my position as both an insider and outsider in certain respects reflected the true nature of qualitative research. As an outsider, I was an international student and came from different educational systems, and a different background and culture. In my country, immersion schools do not exist and if there were some, they would be very limited and not for the general public. During the procedures of this study, I have rethought my position a bit. Dorner, Orellana, Meza, and Pulido (2002) wrote that, "What we have found throughout our group process is that while I may not be an 'insider' to the experience of the bilingual children or their translation experiences, I am more or less an 'insider' to the parents' experiences surrounding translation..." (p. 15). I have gone through these experiences as a second language learner as

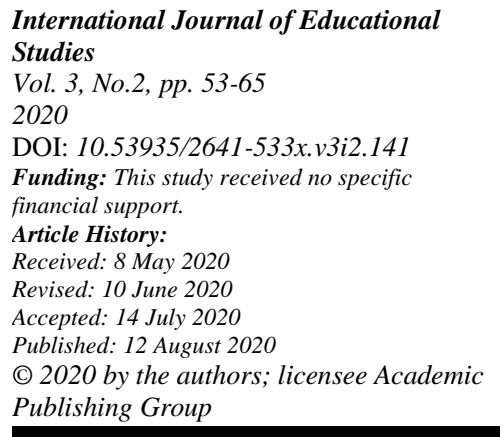


well as a teacher of language; I liked to use different teaching strategies to have my students achieve their goals.

\subsection{Data Collection}

Data collection for this project took place over three months during the spring of 2015. The data is based on two observations in Mrs. Nancy's and Mrs. Julia's immersion classrooms, as well as an interviews with them, also an interview with Mrs. Maria, a Spanish teacher. The interviews were recorded in a voice recorder and in the Voice Memos application of the Smart phone. Later, the voices were became written transcripts. The observations were recorded first, then transferred into the fieldwork observations.

For both observations, I was prepared and ready. According to Merriam, "Training and mental preparation is as important in becoming a good observer..." (p. 118) I believe the best training is making a guideline from research books such as those written by Creswell and Merriam, or from qualified studies as well. To start the observation one should "identify who or what to observe, when, and for how long".

Therefore, I observed the sixth grade in a Mid-west city language immersion school. The aim of the observation was to see how a French teacher teaches a subject in students' second language. I observed what kinds of strategies the teacher used during the immersion class. I watched how Mrs. Julia and Mrs. Nancy give the class instructions, how they push their students to learn, how students respond to them, how students communicate in a classroom in which a different language is spoken, and how students work to master the class materials within their immersion program. Further, I observed what students did during class and outside the class, their behavior when they heard different languages, their most common challenges, and their successes. Additionally, I observed the materials given to them, what the classrooms looks like, ... etc. Each observation was for the whole class, a 90 minute period of time. Mrs. Nancy's class was planned for French Social Science class but it was changed to a French linguistic and literature class. Mrs. Julia's class was a Spanish Science class. Most importantly, Creswell (2007) suggested that the observers should record the participants' quotes and I tried to quote as much as possible the participants' ideas, comments, responses and thoughts. This was the hardest procedure during the observation method because of the different languages.

Merriam (2009) also recommended drawing a diagram to help recall what was happening during the observation. I did that and it was very helpful.

As previously mentioned, I interviewed three teachers: two whose classes were observed and the third teacher who was the Spanish Science and Spanish Math teacher. She was a full time teacher and she moved between the international school and a Spanish immersion school. Each interview was about 40 minutes long. Actually, Merriam (2009) provided great context for better understanding and conducting the interview process. Interviewing "is necessary when we cannot observe behavior, feelings or how people interpret the world around them" (p. 88). Even though the students have been succeeding in immersion programs and greatly achieving two-language acquisition, immersion teachers go through some challenges that make their teaching harder than that of teachers in other schools, and this was discovered in the interviews. Additionally,

Merriam (2009) grouped the interview into three types. The first is highly structured, where the wording of questions is predetermined and the interview questions should be in order. The second type is semistructured where the researcher uses an interview guide, including a mix of more and less structured questions. The last type is an unstructured or informal interview, where the interview is more likely a conversation with more flexibility and exploration. In fact, I moved between the second and third types. My interview was the oral form of a written survey and I asked questions without stopping them and gave them the opportunity to speak more then I spoke. However, I kept in mind suggestion, which is that "asking appropriate questions and relying on participants to discuss the meaning of their experiences requires patience and skill on the part of the researcher" (p. 140).

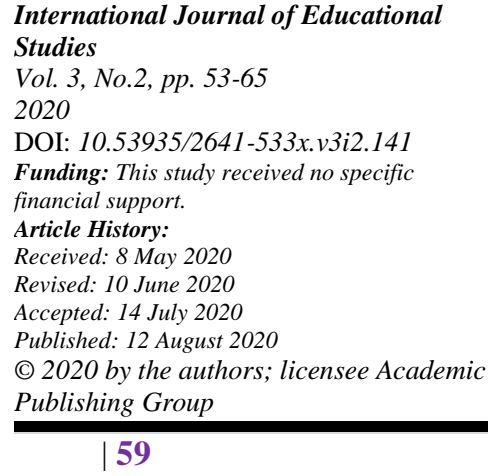

\subsection{Data Analysis Procedures}

Spradly (1980) mentioned that the more information you have, the easier it is to analyze. I wished to have more data but time was limited and the project was only for class practice. The data were analyzed utilizing a grounded theory approach. Even though grounded theory was not actually used in the study design, the grounded theory approach involves a process of creating codes and utilizing the codes to develop categories and concepts of the data (Charmaz, 2010; Creswell, 2007). The data analysis started with the initial 
transcription of the jottings and notes taken during the observations, including the analytical memos written during the observation process. During the transcription process, jottings became more formalized set of field notes. The initial analytical memos made during the observation process were expanded, clarified, and providing an opportunity to add more context and perspective to the initial fieldwork jottings. After each fieldwork transcription was completed, the process described above was repeated.

Each piece of data was continually analyzed and reanalyzed, starting with an open coding process. Open coding involves breaking down, examining, comparing, and categorizing data, and is usually the initial step in the grounded theory process (Corbin \& Strauss, 2008). Open coding provides an opportunity for the researcher to start the data analysis procedure and to begin to conceptualize and contextualize the information. For this study, open coding started approximately midway through the data collection process as I became more aware of the steps and procedures involved. After gaining experience with the open coding process, open coding took place after each fieldwork or interview transcription was collected. I also returned to previous fieldwork documents to reanalyze and recode as necessary, since different concepts emerged from the data. The open coding also fostered the creation of early categories to initially sort and structure the data.

The open coding process included reading and rereading over approximately 70 pages of field notes and interview transcriptions. During the open coding process, a good number of separate open codes were created from the data. Analytical memos made prior to and during the coding process helped to guide and inform the consolidation and refinement of the codes. At the end of this phase, five different categories had been created.

Axial coding was the next stage of the data analysis. It connected the pieces of data that seemed to be a part of one group. Merriam (2009) explained, "This process of grouping your open codes is sometimes called axial coding or analytical coding"(p. 180).

Moreover, I followed Creswell (2007) suggestion for the process of axial coding, which is that the researcher reviews the data and provides the database and concept insight into specific coding that relates to and explains the core categories. The next step is sorting categories. During the time that I was collecting the data, I wrote my reflections in both fieldwork and interview transcriptions. I also used memo writing, which is considered "the intermediate step between coding and the first draft of the completed analysis" (Charmaz, 2010). Actually, memo writing helped me a lot in creating categories. I asked questions, made some comparisons, looked for the similarities and differences between my notes and reread the data in more depth to make categories. Therefore, the procedure to build categories was informed by Creswell (2007) "the researcher examines the text for salient categories of information supported by the text. Using the constant comparative approach, the researcher attempts to "saturate" the categories--to look for instances that represent the category and to continue looking and interviewing until the new information obtained does not further provide insight into the category" (p. 160).

Therefore, I tried to manage the number of categories. I deeply focused on my research topic. I have categorized my data into five categories, and during this process I noticed that some categories could become subcategories and this was mentioned by Merriam (2009)"some original categories will probably become subcategories" (p.182). Also, I reviewed the data and the categories once more to see if I missed some important information or if I could come up with a new category. The next step was naming these categories and I followed Merriam (2009) process which is that "the name of your categories can come from at least three sources (or a mix of these sources): yourself, the researcher, the participants, or sources outside the study of the literature" (p. 184). Thus, I mostly named the categories from the literature review.

Creating subcategories, defined by Merriam (2009) as, "The process of relating categories and properties to each other, refining the category scheme" (p. 200). Based on this, I reread my data and I tried to match some concepts to the core categories. In fact, I could not stop collecting data and I would also continually analyze the data, in keeping with Spradly (1980) who said that at some point, the researcher should stop collecting data and stop analyzing the data as well.

To reemphasize, I used only two methods for collecting the data, and I added into these two methods the reflections and memo writings in both field note observations and interview transcriptions. This strategy led me to focus more on the area of research. Other researchers use multiple methods to focus on different levels of inquires, and to examine the participants' experiences for a long time. This strategy mentioned by Merriam (2009) and she named this strategy "triangulation" which basically means that the researchers use three strategies to collect data. Merriam grouped triangulation into four types: multiple methods, multiple data

Studies

Vol. 3, No.2, pp. 53-65

2020

(93/2641-533x.v3i2.141

Article History:

Received: 8 May 2020

Revised: 10 Jun 2020

Published: 12 August 2020

(C) 2020 by the authors; licensee Academic Publishing Group 
resources, multiple investigations, and multiple theories. As a matter of fact, I use in this study multiple data collection methods, and there was a peer review of my data, including the reflections and memos writing during data collection, to meet the triangulation strategy in this study.

\section{The Findings of this Study}

In fact, the findings of this study answered the research questions and also related to previous studies and my personal rationale. I will later include some areas that need more investigation; the limitation of this study will also be addressed. I will mention what I believe to be most important findings by providing evidence from study participants. The data analysis shows that the immersion school's environment is helpful for bilingual students.

Secondly, even though the immersion school is a good way to learn language, there are some challenges that can make the learning harder. Thirdly, students in immersion schools have different characteristics than other students in regular education, and fourthly, there is a question about which teaching strategies are most usable in immersion school classrooms. Finally, motivation is positive effectually on the teaching strategies as well, as it pushes the learners to learn.

\subsection{Immersion Schools' Environments}

Bilingual education or an immersion school is a good approach for acquiring languages and developing subjects. Immersion schools help students to achieve their second language acquisition and help them in the future to have the ability to access different languages of curriculum. Immersion schools have many features that are different than other schools and these features are going to help students to combine their second language acquisition with developing their first language. Immersion school employees are different than those in other schools. Mr. Jeff speaks four languages, Mrs. Julia speaks two languages fluently and she understands another two languages, Mrs. Nancy and Mrs. Maria speak two languages fluently. All teachers have good experience in dealing with students with different backgrounds, cultures, and languages. For example, "This principal is an American from Virginia and he has good experience in dealing with language immersion schools. He was a principal for three years in a private international school in Colombia. His former school is an English school; the school instruction and school subjects are given in English while the students are native Spanish speakers" (Faisal, Field note, Feb 17,2015). Plus, Mrs. Nancy lived and worked in a bilingual environment. "I taught French for 12 years when I was living in England. I taught Middle and High school.

And now I have worked this last year at the French school which is part of the Midwest city schools" (Nancy, interview transcription, March 27, 2015)

The immersion school's environment is also different from other schools. Mrs. Nancy's classroom is the French version, "All posters in the class were written in French; there was not any English poster at all." (Faisal, Field note, Feb 24, 2015). When I observed the class, it was oriented differently than the other two classes I had already observed. We seemed to move from English to French surroundings. Everything in the classroom is in French. I liked the classroom setting and I felt that I was living in a French-speaking country, not in the U.S. Mrs. Julia's classroom was similar to Mrs. Nancy's classroom and "In the classroom there were: a white board, overhead projector, and all posters were written in Spanish" (Faisal, Field note, Feb 20, 2015). Furthermore, class instruction in the immersion school is divided into two languages, depending on the students' second language proficiency. For example, Mrs. Julia's class instructions were " 90 to 10 . In my classroom, 90\% Spanish 10\% English, I try not to use English, but if I..." (Julia, interview transcription, April 23, 2015).

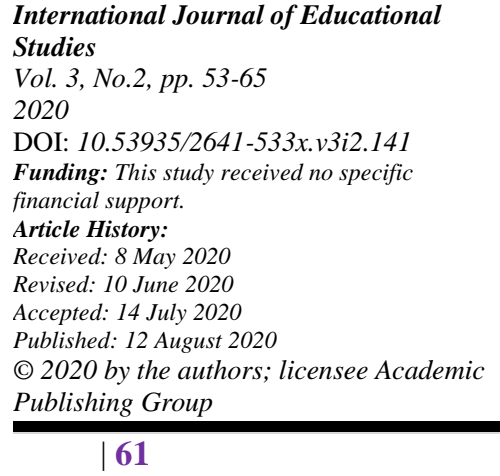

\subsection{The Challenges That Face Immersion School}

All these features of immersion schools are going to help students to acquire both first and second language. Although immersion school is different than other schools, there are some challenges that can make the learning harder than in other schools. For example, finding resources in both languages, and mixed students' language ability levels in the immersion classroom are challenges for immersion programs. Mrs. Maria confirmed that:

"Maria: So resources are always very difficult.

Faisal: Resources? 
Maria: So finding resources that I can use for both classes in English and in Spanish that has been difficult. I'm about to look for math books, so I need to look for math books in English and in Spanish, you know, and it helps if it's the same math book. I was able to get science books that are in English and in Spanish and they're really great, so I want to find something like that. So that one's in the diversity, okay, so that one's...that one's in English... and this one is in Spanish. So it's the same book, same pages, same questions, same everything, it's just in a different language. So really, because I teach the classes..." (Faisal, Field note, March 27, 2015).

\subsection{Language Teaching Strategies}

The main purpose of this study is to examine the teaching strategies in immersion classrooms. As mentioned earlier in the literature of review, there are a good number of teaching strategies used in the immersion classroom. There are agreements between the literature review and the findings of this study. In this study, teachers use active learning strategies, cooperative learning, cognates, translation activity, and structural approach. Mrs. Nancy said that:

"I use cognates, I use cognates as much as I can. Obviously, because my students are sixth graders, I can rely on visuals in writing, so again, that would be cognates, but in writing. I ask students who have done French before to help me translate. If we look at the text, we look at key words; we identify the keywords we need to help us understand the gist. I'm just trying to communicate, just using French, not for teaching purposes but just as a communication language as much as possible, which I know I could do more of, but..." (Nancy, interview transcription, March 27, 2015).

The cognates strategies basically are words in two languages that share a similar meaning, spelling, and pronunciation, though English may share very few cognates with a language like French. Also, cognate awareness is the ability to use cognates in a primary language as a tool for understanding a second language. Moreover, Mrs. Nancy used cooperative learning:

"at the end of every social studies unit, when they do a project in groups, that's for sure. We did it for a whole unit in design. The whole unit, they were working in teams. We did it yesterday for one activity in French, but that was just one activity, maybe once every lesson?" (Nancy, interview transcription, March 27, 2015).

The structural approach, defined in the literature review as advanced, is also used in this school. For example, Mrs. Julia stated that:

"The first, and I think this, you have to apply this not only in an immersion context but in any other context of learning, any subject - Krashen's Theory of Comprehensible Input, i+1, it has to be done. They know something but you always have to go a little bit above, a little bit further. For that, of course, you need another strategy: visual aids, body language, use what you've got" (Julia, interview transcription, April 23, 2015).

\subsection{Motivation Matters in Teaching Language at Immersion Schools}

The most important finding of this study was motivation. While collecting the data by using the observation and interview methods, I found that these strategies work very well if accompanied by motivation, and the opposite is also true. I really liked Mrs. Julia's thoughts when she said students need to be motivated in all teaching strategies. According to Mrs. Julia, "[motivation] just that little thing, is going to lower their anxiety level and they are going to be more willing to participate" (Julia, interview transcription, April 23, 2015). Motivations in learning can be oral support, such as Mrs. Julia motivational words "I am glad you were able to concentrate today while you had to read for 5 minutes, I'm glad you could do that" (Julia, interview transcription, April 23, 2015). The example of motivating actions was evident in Mrs. Nancy classroom, "Mrs. Nancy motivated her students by giving them high fives, clapping, and using supportive words" (Faisal, Field note, Feb 24, 2015). Plus, I observed some activities, like the timer activity, used in Mrs. Nancy in her French classroom that motivated students to learn and made them more willing:

"The next activity was multiple questions that needed to be answered by the students. The questions were written on the smart board and the students had to answer them on a separate sheet. She gave them five minutes and she used a timer. The students worked on this activity until the timer rang. All students wrote their sentences on the smart board and Mrs. Nancy helped them and corrected them as well. (They spoke French fluently and they wrote in French, but their writing was not as good as their speaking.) Students

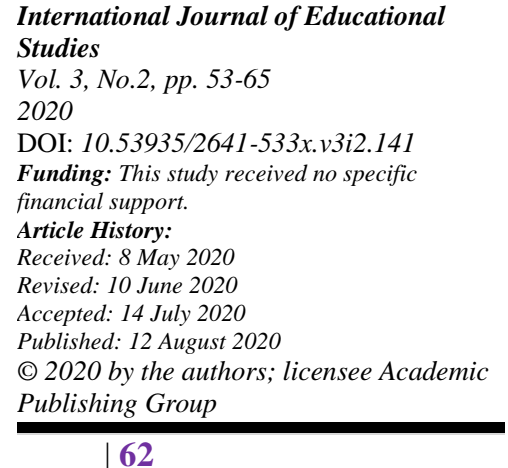


enjoyed doing this activity with the timer and each one of them was trying to finish the sentences first. (This was the same first activity of asking questions and having the students fill $t$ in the blanks, except with the timer. The timer made the students more active and the work seemed more enjoyable, but there was not a difference with the first activity) All instructions were given in French and students were participating in French, with very limited English" (Faisal, Filed note, Feb 24, 2015).

Another motivation activity, observed as well in Mrs. Nancy class, was a crossword activity:

"The last activity was more interesting for students.(For me as well and I wished I knew French and could participate.) Each student was eager to play.. It started at 1: $42 \mathrm{pm}$. It was a crossword game on the smart board. In the game, there were four columns and each column had five to six letters. (This activity reactivated the class and moved them from regular activities to special ones. Also, they were moving away from routine, repetitive activities to more fun activities.) Each student individually chose the letters to create the right French word. The first student spent more than one minute to solve the first game. When he finished, Mrs. Nancy wrote his name and his score on the small white board, which was located on the right side of the class. All information was written in French and his score was 2.43 out of 84 . The second student spent more time and he scored 0 out of 84 . The last student chosen was Kita. Even though she faced some challenges in completing the game, she was willing to complete the game and scored higher than the first student. Unfortunately, Mrs. Nancy stopped her because they were out of the time. (I really felt sorry for her.She tried to do her best and her friends were clapping and encouraging her. I couldn't believe how her teacher and her classmates motivated her.) Students were happy with this activity and each student liked being selected by the teacher. Also, when a student was working on the game, his classmates were helping him and trying to get the right letter to create the right word" ((Faisal, Filed note, Feb 24, 2015).

\subsection{Immersion Students and Second Language Acquisition}

Regarding immersion schools students, they have different cultures, different backgrounds, and they are different colors. Students in immersion schools have different categories from students in regular schools. When students use two languages in the classroom, they have more self-confidence. Mrs. Maria talked about students in her class, " [they] have a lot of self-confidence to read, and they just know they're going to read it wrong, but then we will fix it" (Maria, interview transcription, March 27, 2015). Even though students make mistakes, they can fix and correct these errors without shyness or being afraid of making mistakes. Also, students in immersion schools are always supported and engaged by their parents. The Midwest City Language Immersion Schools accept any students who want to study in an immersion classroom,. They do not require that families live in the school's same district to enroll children in the schools; students come from all over the city.

Therefore, parents enroll their children in this kind of program because they value having bilingual children. According to Mrs. Nancy:

"Okay, first of all, I don't think many parents believe that because they are well informed when they sign up their students to this school, they know that...a lot of parents choose this school, and I mean, when I say school, I mean all the Midwest City schools, they choose this school so their kids will have that experience. So, I don't think it's a problem. Because if they didn't want them to have the immersion, they would take them to their neighborhood public schools" (Nancy, interview transcription, March 27, 2015).

Beside the students' support from their parents, students have strong relationships with teachers. Mrs. Julia told me how her students like to meet her regularly and they always ask for help and always ask for correction of their pronunciation. Also, those students inside the immersion classroom speak their second language and when they get out of the classroom, they speak their first language. Mrs. Julia pointed out that those students, by the end of the academic year, perform better in their second language and they speak more than in the beginning of the academic year. Those students have the ability to move easily between their first and second languages. Second language researchers call this achievement "Switch Coding," where students speak their second language in the classroom and speak their first language outside the classroom.

The other finding of this study was second language acquisitions. All immersion teachers who participated in this study agreed that the best age to enroll in immersion schools and develop languages is at age 5 in kindergarten. Mrs. Maria stated:

"...I would say an immersion school, it depends on when a student starts. That is a huge factor. I mean, like all the research we learn as educators tells us that students learn a language, or the best time to learn a

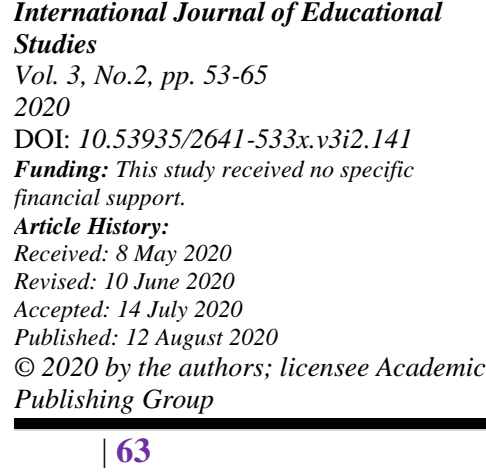


language, is when they are young and their brain is open for it. I definitely think an immersion school would be better as long as they offer it at the primary level" (Faisal, Field note, March 27, 2015).

\section{Conclusion}

This paper has discussed the teaching strategies used in immersion schools. Most teachers in the study use the cognate strategy, which is also confirmed by second language researchers. A cooperative strategy is also widely used in teaching in general, and especially in the area of teaching languages. Additionally, a structural approach was also recommended in previous studies for use in immersion schools, and this approach was used in the site of this study. Those teaching strategies were mentioned in the literature review.

However, although these strategies are very useful, without motivation learning is going to be very limited. Educators believed that motivation is the first key to have students successful and to help them to achieve their academic achievements. This relates to the studies discussed herein. Furthermore, most studies confirm that students in immersion schools have positive feelings and are more intelligible because they have the ability to read, write, and speak in different languages. Even though I have noted the use of three collection methods or three different times of investigation, the reflections and memos on collected data could be the strength of the study as a triangulation strategy which was mentioned previously. However, even though those students are successful, there are some challenges that can make them less successful if these challenges are not solved. Thus, I can open the door for the researchers to go deeper in studying the area of challenges that may face both teachers and students in immersion schools. There is also a gap in the area of teaching strategies because it is general topic; thus, I suggested extra research investigation on one particular strategy. There is some research about cognates, but there are still some limitations in the other strategies.

The limitation of this study is the small number of interviewees and observations; thus the result cannot be generated or transferred. Also, the time was very limited and as a result I could not investigate deeply. If I had further time, I would do survey questionnaires for all teachers who work full time and part time in all four schools in the Mid-West City language immersion schools. In addition, this school is still under development. In other words, the logistics of conducting research in a place where staff and faculty are still working on smoothing school operations while adjusting to the new location may not apply for other immersion schools.

In summary, this paper presents the most useful teaching strategies used in immersion classrooms that help immersion students to acquire their second languages through teaching them both languages and different subjects. Motivation is also the best key for having valuable teaching strategies in the classroom in general and perhaps even more so in language classrooms specifically. Those findings came from a basic qualitative method and the data was collected thought observations and interviewing immersion school teachers. The data was analyzed by following ground theory's process in analyzing the data. The implications and limitations were briefly addressed in this paper.

\section{References}

Abbasi, A. M. (2011). A survey of teaching strategies in ESL classroom. Language In India, 11(11), 313-329.

Al-Mansour, N. (2009). Bilingualism and the need for early EFL education in the Kingdom of Saudi Arabia. Journal of King Saud University - Science, 21(1), 1-12.

Bialystok, E. (2001). Bilingualism in development. Language, literacy and cognition. Cambridge: University Press.

Bialystok, E., Barac, R., Blaye, A., \& Poulin-Dubois, D. (2011). Word mapping and executive functioning in young monolingual and bilingual children. Journal of Cognition and Development, 11(4), 485-508.

Carlson, S. M., \& Meltzoff, A. N. (2008). Bilingual experience and executive functioning in young children. Development Science, $11(2), 282-298$.

International Journal of Educational Studies

Vol. 3, No.2, pp. 53-65

2020

DOI: $10.53935 / 2641-533 x$.v3i2.141

Funding: This study received no specific

financial support.

Article History:

Received: 8 May 2020

Revised: 10 June 2020

Accepted: 14 July 2020

(C) 2020 by the authors; licensee Academic Publishing Group
Charmaz, K. (2010). Constructivist methods. In W. Luttrell (Ed.), Qualitative educational research: Readings in reflexive methodology and transformative practice (pp. 183-207). New York: Routledge.

Corbin, J., \& Strauss, A. (2008). Basics of qualitative research: Techniques and procedures for developing grounded theory (3rd ed.). Thousand Oaks, CA, US: Sage Publications, Inc.

Creswell, J. W. (2007). Qualitative inquiry research design: Choosing among five traditions. California: Sage Publication.

Cummins, J. (1998). Immersion education for the millennium: What have we learned from 30 years of research on second language immersion? Learning through two languages: Research and practice. Second International Symposium on Immersion and Bilingual Education. pp. 34-47.

Cummins, J. (2009). Bilingual and immersion programs. In M. Long and C. J. Doughty (Eds.) The handbook of second language teaching (pp. 161-181). Oxford: Blackwell Publishing.

Cummins, J. (2007). Rethinking monolingual instructional strategies in multilingual classrooms. Canadian Journal of Applied Linguistics, 10(2), 221-240. 
Dorner, L. M., Orellana, M. F., Meza, M., \& Pulido, L. (2002). Reflections on the process of team ethnography: Beyond race, class, and gender. Inquiry, 6(1), 65-87.

Dornyei, Z. (2008). Motivation and motivating in the foreign language classroom. The Modern Language Journal, 78(3), $273-284$.

Garica, O., Flores, N., \& Chu, H. (2011). Extending bilingualism in U.S. secondary Education: New variations. International Multilingual Research Journal, 5(1), 1 - 18

Grosjean, F. (1982). Life with two-way language. An introduction to bilingualism. Cambridge, MA: Harvard University Press

Merriam, S., B. (2009). Qualitative research: A guide to design and implementation. Hoboken: NJ: Jossey-Bass.

Portes, A., \& Hao, L. (1998). Pluribus Unum: Bilingualism and loss of language in the second generation. Sociology of Education, 71, 269-294.

Rahman, F., Jumani, N. B., \& Basit, A. (2010). Motivating and de-motivating factors among learners. International Journal of Academic Research, 2(1), 206-212.

Sampath, K. (2005). Effect of bilingualism on intelligence. International Symposium on Bilingualism, 4, 2048 - 2056.

Slavin, R., \& Cheung, A. (2005). Effective reading programs for English language learners and other language- minority students. Bilingual Research Journal, 29(2), 241-267.

Spradly, J., P. (1980). Participant observation. New York: Holt, Rinehart and Winston.

International Journal of Educational Studies

Vol. 3, No.2, pp. 53-65

2020

DOI: $10.53935 / 2641-533 x . v 3 i 2.141$

Funding: This study received no specific

financial support.

Article History:

Article History:
Received: 8 May 2020

Received: 8 May 2020

Accepted: 14 July 2020

Published: 12 August 2020

() 2020 by the authors; licensee Academic

Publishing Group 